\title{
Avoiding impacts on biodiversity through strengthening the first stage of the mitigation hierarchy
}

\author{
Ben Phalan, Genevieve Hayes, Sharon Brooks, David Marsh, Pippa Howard \\ Brendan Costelloe, Bhaskar Vira, Aida Kowalska and Samir Whitaker
}

\begin{abstract}
The mitigation hierarchy is a decision-making framework designed to address impacts on biodiversity and ecosystem services through first seeking to avoid impacts wherever possible, then minimizing or restoring impacts, and finally by offsetting any unavoidable impacts. Avoiding impacts is seen by many as the most certain and effective way of managing harm to biodiversity, and its position as the first stage of the mitigation hierarchy indicates that it should be prioritized ahead of other stages. However, despite an abundance of legislative and voluntary requirements, there is often a failure to avoid impacts. We discuss reasons for this failure and outline some possible solutions. We highlight the key roles that can be played by conservation organizations in cultivating political will, holding decision makers accountable to the law, improving the processes of impact assessment and avoidance, building capacity, and providing technical knowledge. A renewed focus on impact avoidance as the foundation of the mitigation hierarchy could help to limit the impacts on biodiversity of largescale developments in energy, infrastructure, agriculture and other sectors.
\end{abstract}

Keywords Biodiversity offsets, conservation policy, mitigation hierarchy, Net Positive Impact, No Net Loss

\section{Introduction}

The development of mines, infrastructure, buildings and I plantations changes landscapes and seascapes profoundly, putting pressure on biodiversity and often reducing the provision of important ecosystem services. The mitigation hierarchy is a decision-making framework developed with

Ben Phalan (Corresponding author) Conservation Science Group, Department of Zoology, University of Cambridge, Downing Street, Cambridge, CB2 3EJ, UK, and Department of Forest Ecosystems and Society, Oregon State University, Corvallis, Oregon, USA. E-mail benphalan@gmail.com

Genevieve Hayes, Aida Kowalska and Samir Whitaker BirdLife International, Cambridge, UK

Sharon Brooks UNEP-World Conservation Monitoring Centre, Cambridge, UK David Marsh and PipPa Howard Fauna \& Flora International, Cambridge, UK Brendan Costelloe Royal Society for the Protection of Birds, Sandy, Bedfordshire, UK

BHASKAR VIRA Department of Geography, University of Cambridge, Cambridge, UK

Received 17 September 2015. Revision requested 4 November 2015.

Accepted 5 September 2016. First published online 11 January 2017. the aim of preventing and remediating environmental impacts from such developments. It requires developers to first avoid impacts where possible. Where impact avoidance is not possible, developers should strive to minimize impacts, to restore affected areas and, finally, to offset any remaining residual impacts (McKenney \& Kiesecker, 2010; Clare et al., 2011; BBOP, 2012a; Gardner et al., 2013).

The first part of the mitigation hierarchy, impact avoidance, requires developers to 'anticipate and prevent adverse impacts on biodiversity before actions or decisions are taken that could lead to such impacts' (Ekstrom et al., 2015). Impact avoidance is typically identified as the most important stage of the mitigation hierarchy (McKenney \& Kiesecker, 2010; Clare et al., 2011; Ekstrom et al., 2015). In principle, impact avoidance can reduce the need for remediation, thus side-stepping problems such as restoration time lags, limits to what can be offset, and negative social implications of removing people's access to nature locally and attempting to replace it elsewhere (Bendor, 2009; Maron et al., 2010; Pilgrim et al., 2013a; Ives \& Bekessy, 2015).

In practice, there are concerns that impact avoidance is often ignored, misunderstood and poorly applied by developers, impact assessment practitioners and regulators (Clare et al., 2011; Villarroya et al., 2014). At the same time, there are signs of offsetting being situated in policy as a means to legitimize development that would not otherwise have been permitted (Walker et al., 2009; Ferreira et al., 2014; Sullivan \& Hannis, 2015). Situating offsets as a licence to trash' runs counter to the principle of avoiding negative impacts to the maximum extent practicable, a core tenet of the mitigation hierarchy (U.S. EPA \& DA, 1990; McKenney \& Kiesecker, 2010; BBOP, 2012a).

We review the incentives and requirements for impact avoidance, identify challenges for achieving it, and outline some possible solutions, with an emphasis on the ways in which conservation organizations can advocate for better impact avoidance. There are further details about the issues discussed here, and a wider range of case studies, in BirdLife International (2015) and Ekstrom et al. (2015).

\section{Current incentives, requirements and criteria for impact avoidance}

National laws, voluntary sustainability standards, corporate commitments and pressure from civil society organizations 
all have roles to play in creating incentives and requirements for impact avoidance. Most countries require impact avoidance to be considered as part of the Environmental and Social Impact Assessment process (Pope et al., 2013). Sustainability standards include those set by financial institutions, such as Performance Standard 6 of the International Finance Corporation, as well as sector-specific standards, such as those of the Roundtable on Sustainable Palm Oil. Increasingly, companies are adopting commitments to No Net Loss or Net Positive Impact, which seek to ensure that negative impacts on biodiversity and ecosystem services are balanced (for No Net Loss) or outweighed (for Net Positive Impact) by impact avoidance, minimization, restoration and offsetting (Gardner et al., 2013; Rainey et al., 2015).

In Table 1 we summarize some of the key components (actions and criteria) of standards and laws requiring avoidance, for a set of illustrative instruments. Commonly required actions include consultation, impact assessment, consideration of cumulative impacts, and monitoring. Consulting with local communities and conservation organizations is an important step in identifying impacts that might be considered serious or unacceptable, and that might otherwise not be assessed. Conducting an Environmental and Social Impact Assessment is now standard practice for large developments in most countries but it is less common to consider the cumulative impacts of multiple developments, including off-site, cryptic and secondary impacts (Pope et al., 2013; Raiter et al., 2014). Transparent long-term monitoring and evaluation is essential for demonstrating that commitments to avoid and remediate impacts have been successfully upheld.

Our examples illustrate four recurrent criteria for moving past the avoidance stage of the mitigation hierarchy. The first is that alternatives are given full consideration by regulators and developers, both before and during the Environmental and Social Impact Assessment (Table 1). These can include project cancellation, alternative site locations (spatial impact avoidance), alternative scheduling of activities (temporal impact avoidance), and use of technology and planning within a site (design-based impact avoidance; Table 2).

Early consideration of alternatives is advisable, alongside early engagement with a full range of stakeholders to identify appropriate alternatives (Ekstrom et al., 2015). The cost of altering a project is lower early in the planning process, before decisions about locations and technologies are locked in and the range of feasible alternatives is narrowed. Planning tools can facilitate access to data on existing conservation designations and thus help to screen alternative sites, such as the Integrated Biodiversity Assessment Tool (IBAT, 2015) and national land-use planning and protected area databases (Ekstrom et al., 2015).

A second common criterion for proceeding past the avoidance stage is that the societal benefits of a project should outweigh its environmental costs. The European Habitats Directive provides some of the clearest guidance here. Impacts on priority habitats and species are permitted only for reasons of human health, public safety or environmental benefit, or if there are imperative reasons of overriding public interest' for the project to proceed (Council of the European Commission, 1992; European Commission, 2007). Even here, however, defining when societal benefits are sufficient to justify environmental harm is subjective and often highly political.

A third common criterion for moving past avoidance is delivery of No Net Loss or a net gain in biodiversity (BBOP, 2012a; Gardner et al., 2013). No Net Loss is typically assessed only for priority biodiversity features such as threatened species, critical habitat and areas of high conservation value, even though it could potentially be applied most successfully to common species and ecosystems (Pilgrim et al., 2013b). There are partial exceptions: the UK National Planning Policy Framework, for example, covers wider biodiversity in addition to designated sites (Department for Communities and Local Government, 2012). However, the Framework's reliance on the concept of significant harm means in practice that small, cumulative impacts to common species are likely to be ignored. No Net Loss obligations can often be met through a promise of remediation as well as through impact avoidance and minimization (BBOP, 2012b).

Fourthly, legal requirements can help to define opportunities for impact avoidance, such as through identifying protected sites and species. Laws also set requirements for planning and define how Environmental and Social Impact Assessments should be carried out, and where they are contravened they provide the basis for conservation organizations to challenge failures to avoid impacts in the courts.

\section{Challenges for effective impact avoidance}

We reviewed the literature and drew on our experiences to identify challenges for effective impact avoidance in five broad and often overlapping categories: political will, regulation, process, capacity and technical knowledge (Table 3). Political will refers to the perceived importance among decision makers of avoiding impacts on biodiversity, relative to other concerns. In the absence of political will, laws are less likely to be enforced, expensive alternatives are more likely to be ruled infeasible, and legal protection is at risk of being weakened or corrupted to cater for powerful private interests. Mascia et al. (2014) found over 500 cases of downgrading, downsizing or degazettement of protected areas in 57 countries, most commonly to facilitate industrial-scale resource extraction and development. For companies in the public eye, reputational risk is an incentive to develop the political will to ensure that impacts are reported and avoided (Dawkins \& Fraas, 2011), but for smaller companies, and 
TABLE 1 Examples of voluntary standards and national legislation that set requirements for impact avoidance by defining actions and criteria. Parentheses indicate cases where a requirement is acknowledged but not clearly defined.

\begin{tabular}{|c|c|c|c|c|c|c|c|c|}
\hline \multirow[b]{2}{*}{ Standard or law } & \multicolumn{4}{|l|}{ Actions } & \multicolumn{4}{|c|}{ Criteria for moving past avoidance stage } \\
\hline & $\begin{array}{l}\text { Consult with } \\
\text { stakeholders }\end{array}$ & $\begin{array}{l}\text { Assess } \\
\text { environmental \& } \\
\text { social impacts }\end{array}$ & $\begin{array}{l}\text { Consider } \\
\text { cumulative } \\
\text { impacts }\end{array}$ & $\begin{array}{l}\text { Implement } \\
\text { long-term } \\
\text { monitoring }\end{array}$ & $\begin{array}{l}\text { No viable } \\
\text { lower-impact } \\
\text { alternative }\end{array}$ & $\begin{array}{l}\text { Overriding } \\
\text { public interest }\end{array}$ & $\begin{array}{l}\text { No net impact on } \\
\text { critical biodiversity } \\
\text { features }\end{array}$ & $\begin{array}{l}\text { Compliance } \\
\text { with the law }\end{array}$ \\
\hline $\begin{array}{l}\text { Business \& Biodiversity Offsets } \\
\text { Programme: Standard on Biodiversity } \\
\text { Offsets (2012) }\end{array}$ & $\checkmark$ & $\checkmark$ & $\checkmark$ & $\checkmark$ & & & $\checkmark$ & $\checkmark$ \\
\hline $\begin{array}{l}\text { European Bank for Reconstruction \& } \\
\text { Development: Performance } \\
\text { Requirement } 6\end{array}$ & $\checkmark$ & $\checkmark$ & $\checkmark$ & $\checkmark$ & $\checkmark$ & $\checkmark$ & $\checkmark$ & $\checkmark$ \\
\hline $\begin{array}{l}\text { International Finance Corporation: } \\
\text { Performance Standard } 6^{*}\end{array}$ & $\checkmark$ & $\checkmark$ & & $\checkmark$ & $\checkmark$ & & $\checkmark$ & $\checkmark$ \\
\hline $\begin{array}{l}\text { World Bank: proposed Environmental } \\
\text { \& Social Standard } 6\end{array}$ & $\checkmark$ & $\checkmark$ & $\checkmark$ & $\checkmark$ & $\checkmark$ & & $\checkmark$ & $\checkmark$ \\
\hline $\begin{array}{l}\text { British Columbia (Canada): Policy for } \\
\text { Mitigating Impacts on Environmental } \\
\text { Values }\end{array}$ & $(\sqrt{ })$ & $\checkmark$ & $\checkmark$ & $(\sqrt{ })$ & $\checkmark$ & & & $\checkmark$ \\
\hline $\begin{array}{l}\text { European Union: Habitats Directive } \\
\text { 92/43/EEC, EIA Directive }\end{array}$ & $\checkmark$ & $\checkmark$ & & & $\checkmark$ & $\checkmark$ & $\checkmark$ & $\checkmark$ \\
\hline $\begin{array}{l}\text { United Kingdom: National Planning } \\
\text { Policy Framework } 2012\end{array}$ & $\checkmark$ & $\checkmark$ & $\checkmark$ & & $\checkmark$ & $\checkmark$ & $\checkmark$ & $\checkmark$ \\
\hline
\end{tabular}

${ }^{*}$ Requirements for consultation and impact assessment are established in International Finance Corporation Performance Standard 1. 
TABLE 2 Examples of various types of impact avoidance, and where they are appropriate. Inclusion of projects is solely to illustrate the range of actions that can be taken to avoid impacts on biodiversity, and should not be interpreted as endorsement or a suggestion that best practice was necessarily followed.

\begin{tabular}{|c|c|c|c|}
\hline $\begin{array}{l}\text { Type of impact } \\
\text { avoidance }\end{array}$ & Where appropriate & Example & References \\
\hline $\begin{array}{l}\text { Project } \\
\text { cancellation }\end{array}$ & $\begin{array}{l}\text { Irreplaceable features with no viable } \\
\text { alternatives, \& where offsets unlikely to } \\
\text { succeed }\end{array}$ & $\begin{array}{l}\text { Development permit refused for São Luiz do } \\
\text { Tapajós dam in Brazil } \\
\text { Titanium mine in Cardamom Mountains of } \\
\text { Cambodia cancelled }\end{array}$ & $\begin{array}{l}\text { (Vidal, 2016) } \\
\text { (Hance, 2011) }\end{array}$ \\
\hline Spatial avoidance & $\begin{array}{l}\text { Lower-impact alternative locations can } \\
\text { be identified }\end{array}$ & $\begin{array}{l}\text { Site for desalination plant in Namibia selected to } \\
\text { avoid tern colony } \\
\text { Via Baltica road re-routed to avoid Rospuda Valley } \\
\text { \& other protected sites in Poland }\end{array}$ & $\begin{array}{l}\text { (Aurecon \& SLR, } \\
\text { 2015) } \\
\text { (Niedziałkowski } \\
\text { et al., 2013) }\end{array}$ \\
\hline $\begin{array}{l}\text { Temporal } \\
\text { avoidance }\end{array}$ & $\begin{array}{l}\text { Time periods when activities will not } \\
\text { affect vulnerable features can be } \\
\text { identified }\end{array}$ & $\begin{array}{l}\text { Construction \& seismic surveys suspended during } \\
\text { breeding season of Steller's sea eagles and seasonal } \\
\text { presence of grey whales in Okhotsk Sea, Russia } \\
\text { Logging activities in USA scheduled during dry } \\
\text { periods to avoid erosion \& sediment runoff }\end{array}$ & $\begin{array}{l}\text { (Sakhalin Energy, } \\
\text { 2009) } \\
\text { (Bilby et al., 1989) }\end{array}$ \\
\hline $\begin{array}{l}\text { Design-based } \\
\text { avoidance }\end{array}$ & $\begin{array}{l}\text { Technology \& planning can be used to } \\
\text { modify project components to avoid } \\
\text { specific impacts }\end{array}$ & $\begin{array}{l}\text { Tunnelling equipment used to install pipeline } \\
\text { underground below estuary in Ireland } \\
\text { Logging operations to reuse old access roads instead } \\
\text { of creating new ones in Central Africa }\end{array}$ & $\begin{array}{l}\text { (Shell, 2014) } \\
\text { (Kleinschroth et al., } \\
\text { 2016) }\end{array}$ \\
\hline
\end{tabular}

those without shareholders for whom environmental issues are important, it may not be.

The effectiveness of regulation depends both on the quality of legislation, and its implementation in practice. In Indonesia there is often a mismatch between official maps and the physical reality of land cover, and thus it can be easier for palm oil companies to obtain concessions in primary forest that is classified as non-forest estate on official maps, rather than in the millions of hectares of degraded land that, because it is mapped as forest estate, is legally unavailable for development (Rosenbarger et al., 2013). This is a failure of the legal system for land classification, arising perhaps from a lack of political will to protect primary forests. A review of 11 European projects affecting sites protected under the Habitats Directive found consistent failures by the European Commission in the interpretation and application of the Directive (Kramer, 2009). In only three of these cases were alternative locations assessed, as required by the Directive, and in few if any cases was a robust argument established for the project being of 'overriding public interest' (for further details see Kramer, 2009). In these cases, although the law seems to provide strong protection in principle, it appears to have been undermined by interpretations that privileged economic development and marginalized environmental protection. In the Democratic Republic of Congo, mining rights have been granted within protected areas, even though such areas are legally protected from extractive activities (Javelle \& Veit, 2012). This results from contradictory regulations, inconsistent and outdated government information, a lack of cooperation between the two relevant ministries and, ultimately, opposing interests.
Even while acting within the law, regulators and companies have choices about how to pursue the process of identifying and acting on opportunities to avoid impacts. For example, if impact avoidance is not considered until the Environmental and Social Impact Assessment, opportunities to fundamentally rethink project alternatives may no longer be available. There are incentives, for those who would benefit from a project, to ensure that project cancellation is not considered, and to overlook indirect and cumulative impacts. Because Environmental and Social Impact Assessments and standards are typically applied at a project rather than landscape scale, they are not ideally suited to identifying strategic opportunities for impact avoidance. Within standards, requirements vary, and there is scope for criteria such as those for identifying high conservation values to be interpreted differently by different assessors (Senior et al., 2015). Responsibility for ensuring permanent protection of avoided areas may be unclear: areas avoided during an early phase may be demanded in later stages of a project, and areas avoided by one company may not be avoided by others. For example, Sakhalin Energy's avoidance plans (Table 2) were undermined by Exxon's plans to conduct seismic surveys in the same area (Western Grey Whale Advisory Panel, 2015).

Government departments, companies and civil society organizations all too often lack sufficient capacity and resources to understand, develop and implement sound environmental policies properly (Quétier et al., 2014). National and local governments often lack (or do not allocate) sufficient resources to audit compliance with legislation. Small and medium-sized companies may be unable to afford in- 
TABLE 3 Reasons for the failure of plans and policies to avoid impacts on biodiversity and ecosystem services, and some possible solutions.

Reason for failure

\section{Political will}

Lack of political will to support impact avoidance

Culture within planning authorities of not valuing biodiversity

\section{Regulation}

Legal protection insufficient to ensure impact avoidance

Ineffective judicial frameworks for holding decision makers to account

Failure to avoid impacts to biodiversity that is not considered important

Weak requirements for restoration \& offsetting make remediation more attractive than impact avoidance

\section{Process}

Impact avoidance not considered until Environmental and Social Impact Assessment

Failure to anticipate \& identify likely impacts

Project cancellation not considered

Poor communication between ecologists, engineers, other technical consultants

Failure to adhere to plans

Decision to proceed is made on basis that remediation will compensate for impacts

\section{Capacity}

Lack of resources \& ecological expertise within planning bodies

Poor coordination between conservation \& planning authorities

Lack of permanent protection for avoided areas

\section{Technical knowledge}

Biodiversity data inaccessible or difficult to use

Important biodiversity not prioritized \& identified before development

Limited understanding of trade-offs

Perception that impact avoidance is too costly

Discounting of future costs relative to costs today

Unrealistic assumptions about technical capacity to restore makes remediation more attractive than avoidance
Possible solutions

Harness \& broadcast public support for conservation; expose conflicts of interest; reform institutions giving private interests undue influence Make biodiversity education mandatory for all staff of planning authorities

Incorporate mitigation hierarchy principles into legislation; resist efforts to weaken legislation

Make full use of those judicial frameworks that are effective; lobby for stronger legislation

Set avoidance requirements for biodiversity of all kinds, including common species \& habitats

Enforce detailed, stringent requirements for restoration \& offsetting, including higher bond requirements \& penalties for failure to remediate

Make early stakeholder engagement the industry norm; assess biodiversity risks before Environmental and Social Impact Assessment Audit impact assessments; require assessment of indirect \& cumulative impacts

Require assessment of project cancellation option

Require direct cooperation between consultant teams as part of Environmental and Social Impact Assessment contract

Hold governments, companies accountable to plans

Separate the decision to proceed from any assessment of remediation possibilities

Dedicate resources to create ecologist roles within planning bodies; improve planner-ecologist liaison

Provide resources to integrate conservation planning into local, regional \& national land-use planning

Develop voluntary or regulatory mechanisms to ensure avoided areas receive long-term protection

Improve data availability through platforms that increase ease of use by non-specialists

Comprehensive assessments of important biodiversity at local, regional \& national levels

Incorporate trade-off analysis into Environmental and Social Impact Assessment

Neutral analysis of costs \& benefits of impact avoidance, including non-monetary

Estimation \& communication of future costs \& limitations of restoration \& offsetting

Collate evidence on efficacy of restoration \& offsetting; communicate limits of remediation; use offset multipliers commensurate with uncertainties house expertise on biodiversity and the mitigation hierarchy. Effective impact avoidance may require upfront investments in assessment and planning at a time when there may be uncertainty about whether a project will proceed. Even large companies may be unwilling to incur these costs. The influence of civil society organizations may be limited if they are poorly resourced and have limited expertise, as is common with local groups.
Although knowledge is increasing, there are still many gaps in technical understanding of the spatial distributions and population status of species, especially for plants and invertebrates (Pimm et al., 2014). This makes it difficult to identify and prioritize the sites of most importance in advance of developments. Information on the success and costs of restoration and offsetting efforts is also sparse. Unrealistic assumptions about the capacity and cost of 
restoration and offsetting could result in promises of remediation being a more attractive option for companies than avoiding impacts early in the project cycle. A further challenge is that there may be trade-offs between impact avoidance and other conservation strategies. For example, one way to avoid expanding into natural habitats is to consolidate timber production, farming and infrastructure in existing zones or corridors of disturbance. There is widespread evidence that sparing land in this way would be beneficial for many wild species, even if it increased the per-hectare impacts of development (Edwards et al., 2014; Balmford et al., 2015; Stott et al., 2015). However, some degree of sharing land with multiple uses to reduce the per-hectare impacts of land uses is also desirable, and clear guidance on how to balance these strategies is not available in most places.

\section{Confrontation or compromise?}

Conservation organizations have strategic choices to make about when to collaborate with developers and when to oppose them. Campaigning against harmful developments is important, and this strategy of saying no can help to counterbalance the ambit claims (extreme initial demands) of developers (Laurance, 2016). Opposition is thus an important conservation strategy.

Conservation organizations can also play a role in identifying where developments should take place. A key problem with focusing exclusively on impact avoidance is the risk of leakage, or displacement of impacts. Development avoided at one location is likely to take place elsewhere. Even project cancellation is no guarantee that impacts have been avoided, unless regulation also constrains the demand drivers incentivizing development. Insofar as development is driven by market demands for minerals, energy and other resources, those demands will continue to incentivize further development (Meyfroidt et al., 2013). Thus, it may be as important for conservationists to get involved in defining where development is acceptable as where it is not (Venter et al., 2013; Dinerstein et al., 2015). Mapping priority areas for avoidance also, by implication, often identifies locations that may be more appropriate for development (Bright et al., 2008; Martin et al., 2015).

There are risks involved in both confrontational and collaborative strategies. As conservation interests are typically less powerful than development interests, opposition could leave conservation organizations marginalized and without input into decisions. On the other hand, too much willingness to compromise could result in greenwash, conferring an image of environmental responsibility on companies in exchange for minimal concessions or donations (Robinson, 2012). The best strategy will be context-dependent, and in some situations a combination of principled opposition and pragmatism will be most successful. For example, conservation organizations engaged with local and national authorities to develop standards for new housing developments near the Thames Basin Heaths in the UK. Disturbance-sensitive bird species were protected by avoiding construction within a buffer zone, and developers were required to provide dog-walking areas alongside new housing nearby to minimize additional disturbance (BirdLife International, 2015).

\section{Opportunities for more effective impact avoidance}

There are multiple ways in which conservation organizations can work towards, and support, more effective impact avoidance (Table 3). They can harness and broadcast public support for conservation, thus creating political space for decision makers who want to support impact avoidance (Downie, 2016) and increasing the reputational cost on those who ignore it (Ivanova, 2015). When they can establish or promote particular ways of thinking about issues (frames), they influence the extent to which ecological values are considered in policy development (Sullivan \& Hannis, 2015). Conservation organizations could also play a greater role in challenging corrupt or undemocratic institutions that give private or political interests excessive influence (Greenwald et al., 2012). The success of high-profile campaigns in persuading companies to adopt sustainability standards and zero-deforestation commitments shows how corporate policies can be influenced (Newton et al., 2013; Gibbs et al., 2016).

Regulation can be improved, both in the letter of the law and, perhaps more often, in its application. Conservation organizations can advocate for more stringent requirements for impact avoidance and clearly defined legal protection for sites and species. They can also campaign against subsidies and other perverse incentives for development in areas of biodiversity importance, such as Brazil's proposal to open up to $10 \%$ of its strictly protected areas to mining (Ferreira et al., 2014). Conservation organizations could also campaign to extend stronger protection to common species and habitats, which are sometimes overlooked in legislation (Gaston, 2010). Working informally with state agencies and developers may be fruitful: Malcom \& Li (2015) suggested that informal dialogue in advance of submitting project proposals may have helped to reduce the number of proposals submitted in the USA that would have put threatened species in jeopardy.

There are opportunities for conservation organizations to hold governments and companies accountable to the processes and plans they have signed up to. They can track compliance with legislation and standards, especially in jurisdictions where there is limited capacity for public authorities to do so. They can also push for voluntary actions that make success more likely, such as inclusion of indirect 
and other enigmatic impacts in Environmental and Social Impact Assessments and genuine consideration of project cancellation options. Perhaps the most important demand they can make is for decision makers to consider impact avoidance from the earliest stages of the planning process (Ekstrom et al., 2015). Had this been done in the case of the Via Baltica (Table 2), for example, the case might not have gone to the European Court of Justice, and considerable legal costs and delays could have been avoided.

Building the capacity of individuals and institutions plays a pivotal role in the success of conservation efforts (Brooks et al., 2012). Conservation organizations can support the development of biodiversity-inclusive landscape and regionallevel zoning plans, as well as better policy guidance material to support the implementation and enforcement of legislation on impact avoidance. They can contribute to developing voluntary or regulatory mechanisms to ensure avoided areas receive long-term protection, such as new legal mechanisms for permanently retiring grazing leases on public land (Leshy \& McUsic, 2008). They have also played an important role in the development of voluntary standards, and will continue to do so. For example, Greenpeace played a key part in developing a methodology for identifying areas with high carbon stocks that should be avoided, to address a key gap in the Roundtable on Sustainable Palm Oil standards (Dinerstein et al., 2015).

Conservation organizations can provide tools and technical data to make it easier to conduct cumulative, strategic and environmental impact assessments. Examples include the Biodiversity Risks and Opportunities Assessment tool and the Migratory Soaring Bird Sensitivity Map (BirdLife International, 2015). Conservation organizations can work with other civil society organizations to understand synergies and trade-offs between multiple objectives, and find common ground in advocating for impact avoidance. This may require understanding complex interactions, such as those between conservation and other human interests. It may also involve identifying places where development may be acceptable, as well as those where it should be avoided. A final, crucial role is in better evaluation and communication of the success (or otherwise) of efforts to avoid impacts (Baylis et al., 2016).

\section{Conclusion}

We suggest that a renewed focus on the first stage of the mitigation hierarchy could help to limit the impacts of large-scale developments in energy, infrastructure, agriculture and other sectors on biodiversity. Conservation organizations play an important role in cultivating political will, holding decision makers accountable to the law, improving the processes of impact assessment and avoidance, building capacity and providing technical knowledge. Ensuring that impact avoidance is considered as early as possible in the planning process and that it is placed even more firmly at the heart of the mitigation hierarchy in both policy and practice should be key demands on their agenda.

\section{Acknowledgements}

This paper is a product of a project on strengthening the mitigation hierarchy for greater conservation gains, funded by the Cambridge Conservation Initiative Collaborative Fund. We thank all of the participants in that project, and we are grateful to two anonymous reviewers whose suggestions greatly improved the article. BP was funded by a Zukerman Fellowship at King's College, Cambridge.

\section{Author contributions}

SW, assisted by BP, SB, PH, BC and BV, developed the project idea and wrote the proposal. GH collected and summarized case study data in a report. All authors met to discuss the topic and develop recommendations. BP, assisted by $\mathrm{GH}, \mathrm{SB}, \mathrm{DM}, \mathrm{PH}, \mathrm{BC}, \mathrm{AK}$ and $\mathrm{SW}$, wrote the article.

\section{References}

AURECON \& SLR (2015) Social and Environmental Impact Assessment for the Proposed Rössing Uranium Desalination Plant Near Swakopmund, Namibia. Final SEIA Report, Report No. 9408/110914. Rio Tinto Rössing Uranium Limited, Swakopmund, Namibia.

Balmford, A., GreEn, R. \& Phalan, B. (2015) Land for food and land for nature? Daedalus, 144, 57-75.

Baylis, K., Honey-Rosés, J., Börner, J., Corbera, E., Ezzine-De-Blas, D., Ferraro, P.J. et al. (2016) Mainstreaming impact evaluation in nature conservation. Conservation Letters, 9 , 58-64.

BBOP (2012a) Standard on Biodiversity Offsets. Business and Biodiversity Offsets Programme, Washington, DC, USA.

B BOP (2012b) Resource Paper: Limits to What Can be Offset. Business and Biodiversity Offsets Programme, Washington, DC, USA.

Bendor, T. (2009) A dynamic analysis of the wetland mitigation process and its effects on no net loss policy. Landscape and Urban Planning, 89, 17-27.

Bilby, R.E., Sullivan, K. \& Duncan, S.H. (1989) The generation and fate of road-surface sediment in forested watersheds in southwestern Washington. Forest Science, 35, 453-468.

Bird Life InTERNATIONAL (2015) Strengthening Implementation of the Mitigation Hierarchy: Managing Biodiversity Risk for Conservation Gains. A Cambridge Conservation Initiative Collaborative Fund Project report compiled by BirdLife International, UNEP-WCMC, RSPB, FFI and the University of Cambridge, Cambridge, UK.

Bright, J., Langston, R., Bullman, R., Evans, R., Gardner, S. \& Pearce-Higgins, J. (2008) Map of bird sensitivities to wind farms in Scotland: a tool to aid planning and conservation. Biological Conservation, 141, 2342-2356.

Brooks, J.S., Waylen, K.A. \& Mulder, M.B. (2012) How national context, project design, and local community characteristics influence success in community-based conservation projects. 
Proceedings of the National Academy of Sciences of the United States of America, 109, 21265-21270.

Clare, S., Krogman, N., Foote, L. \& Lemphers, N. (2011) Where is the avoidance in the implementation of wetland law and policy? Wetlands Ecology and Management, 19, 165-182.

Council of THE European Commission (1992) Council directive 92/43/ EEC of 21 May 1992 on the conservation of natural habitats and of wild fauna and flora. European Commission, Brussels, Belgium.

DaWkins, C. \& FraAs, J.W. (2011) Coming clean: the impact of environmental performance and visibility on corporate climate change disclosure. Journal of Business Ethics, 100, 303-322.

Department for Communities and Local Government (2012) National Planning Policy Framework. Department for Communities and Local Government, London, UK.

Dinerstein, E., Baccini, A., Anderson, M., Fiske, G., Wikramanayake, E., McLaughlin, D. et al. (2015) Guiding agricultural expansion to spare tropical forests. Conservation Letters, $8,262-271$.

Downie, C. (2016) Prolonged international environmental negotiations: the roles and strategies of non-state actors in the EU. International Environmental Agreements: Politics, Law and Economics, 16, 739-755.

Edwards, D.P., Gilroy, J.J., Woodcock, P., Edwards, F.A., Larsen, T.H., Andrews, D.J.R. et al. (2014) Land-sharing versus land-sparing logging: reconciling timber extraction with biodiversity conservation. Global Change Biology, 20, 183-191.

Ekstrom, J., Bennun, L. \& Mitchell, R. (2015) A Cross-Sector Guide for Implementing the Mitigation Hierarchy. Cross Sector Biodiversity Initiative, London, UK.

European Commission (2007) Guidance document on Article 6(4) of the 'Habitats Directive' 92/43/EEC. European Commission, Brussels, Belgium.

Ferreira, J., Aragão, L.E.O.C., Barlow, J., Barreto, P., Berenguer, E., Bustamante, M. et al. (2014) Brazil's environmental leadership at risk. Science, 346, 706-707.

Gardner, T.A., Von Hase, A., Brownlie, S., Ekstrom, J.M.M., Pilgrim, J.D., SAVY, C.E. et al. (2013) Biodiversity offsets and the challenge of achieving no net loss. Conservation Biology, 27, 12541264 .

Gaston, K.J. (2010) Valuing common species. Science, 327, 154-155.

Gibbs, H.K., Munger, J., L'Roe, J., Barreto, P., Pereira, R., Christie, M. et al. (2016) Did ranchers and slaughterhouses respond to zero-deforestation agreements in the Brazilian Amazon? Conservation Letters, 9, 32-42.

Greenwald, D.N., Suckling, K.F. \& Pimm, S.L. (2012) Critical habitat and the role of peer review in government decisions. BioScience, 62, 686-690.

HANCE, J. (2011) Cambodian prime minister cancels titanium mine project citing impact on biodiversity and local people. Http://news. mongabay.com/2011/o4/cambodian-prime-minister-cancelstitanium-mine-project-citing-impact-on-biodiversity-and-localpeople/ [accessed 11 March 2016].

ibAT (Integrated Biodiversity Assessment Tool) (2015) IBAT for Business. Http://www.ibatforbusiness.org [accessed 25 October 2016].

Ivanova, M.R. (2015) Influencing corporations through shareholder activism: the case of three NGO-led campaigns in the UK. PhD thesis. Cardiff University, Cardiff, UK.

Ives, C.D. \& Bekessy, S.A. (2015) The ethics of offsetting nature. Frontiers in Ecology and the Environment, 13, 568-573.

Javelle, A.-G. \& Veit, P.G. (2012) Managing Land for Mining and Conservation in the Democratic Republic of Congo. Africa Biodiversity Collaborative Group, Wildlife Conservation Society, New York, USA.
Kleinschroth, F., Healey, J.R. \& Gourlet-Fleury, S. (2016) Sparing forests in Central Africa: re-use old logging roads to avoid creating new ones. Frontiers in Ecology and the Environment, 14, 9-10.

Kramer, L. (2009) The European Commission's Opinions under Article 6(4) of the Habitats Directive. Journal of Environmental Law, $21,59-85$.

LAURAnCE, B. (2016) The world's forests will collapse if we don't learn to say 'no'. The Conversation. Http://theconversation.com/theworlds-forests-will-collapse-if-we-dont-learn-to-say-no-53979 [accessed 15 March 2016].

Leshy, J.D. \& McUsic, M. (2008) Where's the beef? Facilitating voluntary retirement of federal lands from livestock grazing. Environmental Law Journal, 17, 368-397.

Malcom, J.W. \& Li, Y.-W. (2015) Data contradict common perceptions about a controversial provision of the US Endangered Species Act. Proceedings of the National Academy of Sciences of the United States of America, 112, 15844-15849.

Maron, M., Dunn, P.K., McAlpine, C.A. \& Apan, A. (2010) Can offsets really compensate for habitat removal? The case of the endangered red-tailed black-cockatoo. Journal of Applied Ecology, $47,348-355$.

Martin, C.S., Tolley, M.J., Farmer, E., Mcowen, C.J., Geffert, J. L., Scharlemann, J.P.W. et al. (2015) A global map to aid the identification and screening of critical habitat for marine industries. Marine Policy, 53, 45-53.

Mascia, M.B., Pailler, S., Krithivasan, R., Roshchanka, V., Burns, D., Mlotha, M.J. et al. (2014) Protected area downgrading, downsizing, and degazettement (PADDD) in Africa, Asia, and Latin America and the Caribbean, 1900-2010. Biological Conservation, 169, 355-361.

McKenney, B.A. \& Kiesecker, J.M. (2010) Policy development for biodiversity offsets: a review of offset frameworks. Environmental Management, 45, 165-176.

Meyfroidt, P., Lambin, E.F., Erb, K.-H. \& Hertel, T.W. (2013) Globalization of land use: distant drivers of land change and geographic displacement of land use. Current Opinion in Environmental Sustainability, 5, 438-444.

Newton, P., Agrawal, A. \& Wollenberg, L. (2013) Enhancing the sustainability of commodity supply chains in tropical forest and agricultural landscapes. Global Environmental Change, 23, 1761-1772.

Niedziatkowski, K., Paavola, J. \& Jędrzejewska, B. (2013) Governance of biodiversity in Poland before and after the accession to the EU: the tale of two roads. Environmental Conservation, 40, 108-118.

Pilgrim, J.D., Brownlie, S., Ekstrom, J.M.M., Gardner, T.A., von Hase, A., ten Kate, $\mathrm{K}$ et al. (2013a) A process for assessing offsetability of biodiversity impacts. Conservation Letters, 6 , 376-384.

Pilgrim, J.D., Brownlie, S., Ekstrom, J.M.M., Gardner, T.A., von Hase, A., ten KAte, K. et al. (2013b) Offsetability is highest for common and widespread biodiversity: response to Regnery et al., Conservation Letters, 6, 387-388.

Pimm, S.L., Jenkins, C.N., A bell, R., Brooks, T.M., Gittleman, J.L., Jop PA, L.N. et al. (2014) The biodiversity of species and their rates of extinction, distribution, and protection. Science, 344, 1246752.

Pope, J., Bond, A., Morrison-SAunders, A. \& Retief, F. (2013) Advancing the theory and practice of impact assessment: setting the research agenda. Environmental Impact Assessment Review, 41, 1-9.

Quétier, F., Regnery, B. \& Levrel, H. (2014) No net loss of biodiversity or paper offsets? A critical review of the French no net loss policy. Environmental Science \& Policy, 38, 120-131. 
Rainey, H.J., Pollard, E.H.B., Dutson, G., Ekstrom, J.M.M., Livingstone, S.R., Temple, H.J. \& Pilgrim, J.D. (2015) A review of corporate goals of No Net Loss and Net Positive Impact on biodiversity. Oryx, 49, 232-238.

Raiter, K.G., Possingham, H.P., Prober, S.M. \& Hobbs, R.J. (2014) Under the radar: mitigating enigmatic ecological impacts. Trends in Ecology \& Evolution, 29, 635-644.

Robinson, J.G. (2012) Common and conflicting interests in the engagements between conservation organizations and corporations. Conservation Biology, 26, 967-977.

Rosenbarger, A., Gingold, B., Prasodjo, R., Alisjahbana, A., Putraditama, A. \& Tresya, D. (2013) How to Change Legal Land Use Classifications to Support More Sustainable Palm Oil Production in Indonesia. World Resources Institute, Washington, DC, USA.

SAKhalin Energy (2009) Biodiversity Action Plan. Sakhalin Energy Investment Company Ltd., Yuzhno-Sakhalinsk, Russia.

Senior, M.J.M., Brown, E., Villalpando, P. \& Hill, J.K. (2015) Increasing the scientific evidence base in the 'High Conservation Value' (HCV) approach for biodiversity conservation in managed tropical landscapes. Conservation Letters, 8, 361-367.

Shell (2014) Corrib Development Biodiversity Action Plan 2014-2019. Shell E\&P Ireland Limited, Dublin, Ireland.

Stott, I., Soga, M., Inger, R. \& Gaston, K.J. (2015) Land sparing is crucial for urban ecosystem services. Frontiers in Ecology and the Environment, 13, 387-393.

Sullivan, S. \& Hannis, M. (2015) Nets and frames, losses and gains: value struggles in engagements with biodiversity offsetting policy in England. Ecosystem Services, 15, 162-173.

U.S. EPA \& DA (1990) Memorandum of Agreement Between the Environmental Protection Agency and the Department of the Army Concerning the Determination of Mitigation Under the Clean Water Act Section 404(b)(1) Guidelines. U.S. Environmental Protection Agency \& U.S. Department of the Army.

Venter, O., Possingham, H.P., Hovani, L., Dewi, S., Griscom, B., PAOLI, G. et al. (2013) Using systematic conservation planning to minimize REDD+ conflict with agriculture and logging in the tropics. Conservation Letters, 6, 116-124.
VIDAL, J. (2016) Major Amazon dam opposed by tribes fails to get environmental licence. The Guardian. Https://www.theguardian. com/environment/2016/aug/o5/major-amazon-dam-brazilopposed-by-tribes-fails-get-environmental-license [accessed 25 October 2016].

Villarroya, A., Barros, A.C. \& Kiesecker, J. (2014) Policy development for environmental licensing and biodiversity offsets in Latin America. PLoS ONE, 9(9), e107144.

Walker, S., Brower, A.L., Stephens, R.T.T. \& Lee, W.G. (2009) Why bartering biodiversity fails. Conservation Letters, 2, 149-157.

Western Grey Whale Advisory Panel (2015) WGWAP Statement of concern with respect to proposed seismic activity on the Sakhalin shelf in 2015. Http://cmsdata.iucn.org/downloads/ finalcleanwgwapstatement_08_may_final.pdf [accessed 25 October 2016].

\section{Biographical sketches}

Ben PHALAN works on strategies to reconcile human demands for natural resources with the conservation of birds and biodiversity. Genevieve HaYes is working on reducing the deforestation footprint of high-risk commodities such as palm oil, cocoa and rubber. SHARON BROOKS works to improve corporate performance regarding the management of biodiversity and ecosystem services, working primarily with the extractive sector. DAVID MARSH works with the extractive sector to improve understanding and mitigation of site-level impacts on biodiversity and ecosystem services. PIPPA Howard directs Fauna \& Flora International's engagement with the corporate sector. BRENDAN COSTELloE works to influence and improve how biodiversity is incorporated into UK Government planning policy. BHASKAR VIRA directs the University of Cambridge Conservation Research Institute. AIDA KOWALSKA focuses on supporting the development and implementation of biodiversity safeguards in renewable energy developments. SAMIR WHITAKER works on cross-sectoral conservation initiatives, and is particularly interested in environmental risk screening and management for the corporate sector. 